\title{
The Influence of Globalization World Against National Education as Motivation and Challenges Study Case in SMK Nusantara Cintra Tangerang District
}

\author{
Sutarman, Haryono Edihermawan, Dede Farhan Aluwi , LPPPM STKIP \\ Arrahmaniyah \\ Jl. Mesjid Al-Ittihad no.8-12 Bojong Pondok Terong Kec.Cipayung Depok
}

\begin{abstract}
Globalization and education that gave birth to an order of a new society known as the (knowledge based society) which is the beginning of the process of globalization, where the education rapidly developing science that is the foundation of globalization, namely the economic, educational and political world, a sciencebased in society, which is based on education and science are constantly changing and evolving, the reflexivity of human attitudes towards the challenges of a changing world, the ability to reflect, evaluate about his life based on the ratio. Education is very important in realizing the people of the world who think the future is based on education and science, education a process of transformation as well as the future development of science. with the development of highly sophisticated technology connects the nations of this world into a village common, advanced whice village (global village).
\end{abstract}

Keywords: Education, motivation and challenge, Globalization

\section{Introduction}

An era of globalization sweeping across the world community to bring about change effect, positive or negative. The plus side of globalization it is on the advancement of information technology and communication technology. Its negative effects only become the object of globalization without berbua, therefore need mental preparation, faith, and science in the face. needed the ability to filter all incoming influence of western culture, in education or also called the Global Perspective Global education, education that provide a global perspective to equip students and students in entering the era of the globalization, so that they are able to act locally with a global insight. Education that can take advantage of local and global excellence in various aspects of the economy, arts and culture, human resources, languages, information and communication technology, ecology, and others in the school curriculum and implement. Progress communications, IT, as well as a means of global perceived world is getting narrower, limits and barriers becomes opaque state, the process of universalization hit many aspects and joint joints life.

Global internationalization, with this kind of understanding globalization is seen merely `an adjective / adjective to describe the relationship between the borders of various countries'. He described the growth in international exchange and interdependence. The greater the volume of trade and capital investment, the interstate economy is increasingly integrated to the global economy in which the national economy 'distinctive and articulated dissipated back into a system through a process and international agreements'

Global liberalization this sense, the globalization refers to a process in the removal of obstacles - obstacles created by the government to the mobility of relations between countries to create an open world economy, the importance of removing barriers and bulkhead bulkhead global trade.

Global universalization in this concept, with the understanding and the process of globalization is the spread of various schools as objects and experiences to the world, interaction and exchange of information, through the deployment of local area network technology, up to metropolitan area networks.

Global Westernization, a context is understood as a dynamic, where status and social structure of modern capitalism, rationalism, industrialism, bureaucratism, spread throughout the world, which in the process is the tendency of damaging the local culture.Globalization menghapusankan territorial boundaries, as a consequence of globalization, which encourages geographic reconfiguration, so the social space is no longer mapped to the territorial area. Distance territorial and territorial boundaries, globalization is also understood as a process that gave birth to a transformation, organization and social relationships, ekstensitas, intensity, speed, and the impact that memobilitas inter-continental and interregional.

1. Education Globalization limitation, limitations on the globalization of education according to diverse experts, opinions and content is different, because of its orientation, the concept, the basic uses, aspects of which it is intended, and philosophy of the foundation.

2. Globalization Education as a transformation process of acculturation, namely the activities of the mixing of cultures from one generation to another, from one nation to the multi-nation, cultural values are undergoing a process of 
transformation from generation predecessor to the present generation, while the form of transformation and values that still matches forwarded, such as the values of honesty, responsibility, respect each other culture.

3. Globalization Process of Establishing a Personal Education, as the process of personal formation of the nation, as a sign of education a systematic and systemic, targeted, measurable, and the formation of strong personality in accordance with falsapah nation.

4. Globalization of Education as the Printer Labor reliable, Education as production workers, an activity guide the learners that have the provision of basic weeks to become a labor of reliable, as the briefing basic form of education, the formation of attitudes, knowledge, and skills, become important mission of education because work becomes a staple in the survival of the nation.

\section{Globalization of education and supporting elements of which are:}

1. The learners are guided as

2. The Teacher People who educate and guide

3. The interaction between learners with educators are educational interaction

4. Effect of the guidance given in educational materials

5. The method used in the guidance to learners.

6. Place held the environments of education

\section{Proses occurrence of Globalization}

Globalization as a process, not a new phenomenon, as the globalization process has actually been around since the first even centuries, in the late 19th century and early 20th century globalization increasingly heavy and growing rapidly in many countries, when it began to be discovered technology communication, information, and transportation. Globalization spike in increasingly sophisticated technologies, more accurate information, such as the internet and in other media, have proliferated supported by mobile phone, mobile phone with all the features and facilities amenities.

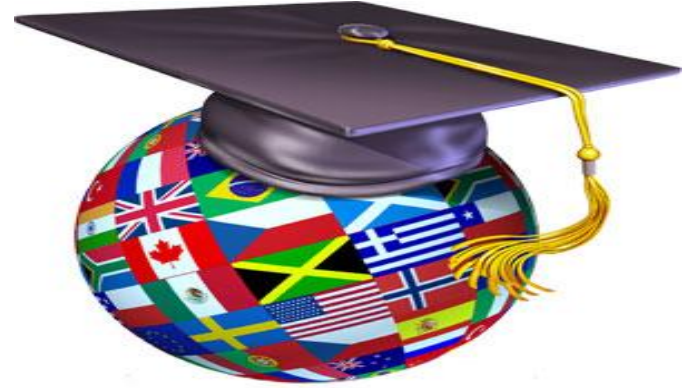

Figure 1. Global Education Symbol

Globalization in Indonesia that is a global process carried out its development process, in all sectors, with the return of experts, technocrats, scientis, economists, Indonesia who run study abroad and the arrival of experts, in consultant from a foreign country, to a process of globalization, good idea or system of values other life, began to be adopted and implemented in accordance with local conditions, globalization is physically marked by the development of infrastructure, the development of cities, skyscrapers, and the splitting of cities and counties, which became part of the network of the world. It can be seen from the telecommunications infrastructure, transportation network, company are international

1. Educate and develop science towards global society

2. Encourage and direct participation in the global community

3. Learners are able to be responsible in life.

4. Being an independent individual

Global Education focuses on:

1. Awareness of the global community perspective

2. The understanding of the systems that embrace the global community

3. An understanding of the local culture of the local culture, language and history of the formation of the global community

4. Tolerance for cultural, religious, ethnic, as well as the existence and the existence of other nations.

Changes Globalization Education happens in many aspects of human life, the beliefs, values, norms, lifestyle, culture, society and the existence of national identity, in the era of globalization Akani emerging global culture, as modern culture if there is an element of education will able to print a modern civilized society.

The process of globalization of education is a process that integrates global life within a space and time become Multinational, good trade, markets, product commodities, banking and finance, culture, supported by facilities and infrastructure system global telecommunications increasingly sophisticated and fast, the creation of a 
network life increasingly integrated. Global culture does not mean the loss of a nation's cultural identity, globalization has stimulated individual consciousness, awareness of ethnic, cultural awareness in a pluralistic community, namely the pluralistic nation, makaseluruh education in Indonesia must have national standards. In attitudes in the face of global change.

\section{Impact of Globalization on Social Affairs and Culture}

Globalization in various sectors, the cultural value of the capitalists in the world community, such as lifestyle, dress, food occur in developing countries, movies and music in the form of a strip, Compek Disk, Video compek disks, and digital compek disk.

The positive impact of globalization in the social sphere is the young people were able to get the tools that allow them to obtain information more informative and can be associated with more efficient and efktif with a wider range,

The negative impact of globalization, namely the younger generation is not ready to be their information, with the resources that are less qualified, will only emulate the things that are not good, as the forms of violence, fights, vandalism, etc.

Advanced facilities makes one reluctant to relate to others, so that a sense of community is much reduced / individualistic.

The benefits of globalization among them is the information that can be obtained by means of an easy, fast and complete, from all over the world so that the knowledge and insight, the human resources is becoming more widespread, but the presence of globalization must be in the filter, do not get all the information received directly, will result in a change in lifestyle, mindset and behavior that does not comply with the norms and culture of the nation. Culture is the sector most vulnerable to its negative impact, because the information and tools that can be accepted by free will affect, in act and think the younger generation.

\section{Impact of Globalization on Social and Economic}

The positive impact of globalization in the field of social economy is to spur productivity and innovation and economic operators, so that the product is able to compete with other products. The era of globalization demands that humans have to be more creative and productive.

Is capable of causing a negative impact of excessive consumerism among the younger generation, so it is not able to meet the demands of the times because it was accustomed to technology and prodksi not only able to buy their own.

Globalization and market liberalism has offered alternative, on the achievement of decent living standards, widening the gap, the distribution of income among rich countries to poor countries. The emergence of giant corporations multinational scale. Opportunities for wealth accumulation and business monopoly and power, as well as the emergence of the world economic institutions such as the World Bank, the International Monetary Fund, WTO, etc.

\section{Product development and innovation}

1. The development of such products, mobile phones, television, and the Internet show that global communication happens so fast, while through the mass movement a kind of tourism allows us to feel a lot of things from a different culture.

2. Market and economic production in different countries become interdependent as a result of the growth of international trade, the growing influence of multinational companies, and the dominance of organizations such as the World Trade Organization (WTO).

3. Increased cultural interaction through the development of the mass media (especially television, movies, music, and transmission of news and international sports). This time, we can consume and experience new ideas and experiences on matters across the wide range of cultures, for example in the field of fashion, literature and food.

4. Increased joint problems, for example in the field of environment, multinational crisis, regional inflation and Iain others.

Anticipation Combating Negative Effects of Globalization on the nation's cultural values as follows:

Policy :

1. Improved understanding and analysis of information from the mass media as filtration values of the original culture of Indonesia.

2. The development of national culture through a multi culturalism based on the values of divinity, humanity, unity, democracy and justice.

3. Always reflect on the history and struggle of the Nation.

4. Realization, socialization and search solutions negative effects of globalization on cultural values of the nation of Indonesia. 
Strategy:

1. Goal realization of national cultural development through a multi-cultural approach is based on the values of divinity, humanity, unity, democracy and justice.

2. Cultural understanding of leadership that is expected to realize the development goals, particularly in the field of national defense.

3. Realization of socializing and finding solutions to the negative effects of globalization cultural values of the nation.

\section{Method}

1. Acculturation of native and foreign cultures for the formation of national culture that support national development

2. Consolidation increased understanding and awareness of the tasks and functions carried in order to achieve the objectives set

3. Regulation and deregulation to arrange and rearrange the laws in accordance with the development environment

4. Coordination among the various parties concerned in order to obtain a common vision to achieve harmony of action in the fight against the negative effects of globalization

5. Education and training to enhance the human resource capabilities in terms of the analysis of the negative influence of globalization

\section{Efforts were made:}

1. Improving the understanding and analysis of information based on the values of the original culture of Indonesia to the upgrading of logic, language analysis and discourse analysis

2. Increasing guidance to religious education, Pancasila and citizenship by improving the understanding and application in everyday life

3. Cultural understanding that is expected to mewujudakan leadership development goals, especially in the field of national defense

4. Filter to foreign cultures by increasing internalization of native culture, the understanding of the values of foreign cultures and analyzes compliance with the original cultural values. Filters for realizing national culture is dynamic and stable.

\section{Global Insight in Education}

How to prepare for the globalization of this is to raise awareness and expand horizons. How to improve and expand the horizons can be done in various ways, and the most effective way is through education.

Improving the quality of education for a nation, however, must be prioritized. Because the quality of education is very important, because the only human quality that can only survive in the future. One way that can be done to improve the quality of education is the education management with global insight. Improve and expand the global perspective is an essential element for understanding global issues.

Through education, one must be able to develop the following four things:

1. The ability to anticipate / Anticipate, education seeks to prepare students to be able to anticipate the development of science and technology ..

2. Understand and address the situation / cope, can develop the skills and attitudes learners to handle and deal with the new situation.

3. Accommodate / acomodate, can accommodate the rapid development of science and technology with all amendments thereto.

4. Mereoriantasi / reorien, perceptions of globalization need to be reoriented for science and technology development and rapid social change.

The importance / urgency of a global perspective in education is an effort in improving the quality of national education, as stated previously, with insights into the global perspective in order to avoid thinking that the narrow and compartmentalized box by boundaries, subjective, so the thought is more developed, the education system other countries that have developed and developing, to study the case of comparing with education in our country, which can be applied and which are sekerdar for information only. We are biased to imitate a good education system in other countries as long as it does not conflict with the Indonesian national identity.

\section{Education Perspectives global perspective}

Kurikulm perspective, based persperktif curriculum, global perspective education is an educational process that aims to prepare skilled manpower from the middle class to the professional level by improving the ability of individuals to understand the society in relation to the life of the world community, with the following characteristics: 
1. Study of cultural, social, political, economic and other nations to understand their focus and related interconnections.

2. Studying the various branches of sciences for the use and benefit in accordance with the needs of the local environment

3. Develop a wide range of possibilities, different abilities, and skills to work together to realize the people's life in a better world order.

\section{Global perspective of education focuses on the discussion covering material}

1. Addiction and attachment between global society

2. Changes and developments will continue from time to time

3. The difference in culture between people or groups in a global society

4. The globalization of the world that has various limitations, in the form of availability of goods for which special, To be able to meet the needs of these rare, it can cause conflicts.

Based on curricular perspective, global vision of educational development has implications toward education curriculum overhaul. Subjects and subjects who developed no longer be monopolitik, but rather the integrative nature, which means that the course is more emphasis on the study is multi disciplinary, interdisciplinary and transdisciplinary.

\section{Perspective Global Reform}

Based on the perspective of education reform globally, is an educational process designed to assign students to the basic capabilities of intellectual and responsibilities, enter the life that is both competitive and interdependence among nations, the educational process takes place in the school with the values of the everchanging society global, schools must have a global value orientations, in which local communities must always relepansi relation to the world community.

Education global perspective by perfective reform, not merely recast the curriculum, but also revamp the systems, structures and processes of education, the basic policy as Social Policy is no longer suitable for the education of global insight, education global perspective should be a combination, the combination of policies that bases the global market mechanism, therefore the structure and system of education should be open, which has the function of economic, educational global perspective is a systematic organic, with flexible adaptive and creative, systemic organic, that the institution is a set of processes that are interactive are not can be seen as black and white, but every interaction should be seen as one part of the interaction of globalization.

Flexible adaptive, meaning that education is emphasized as a process of learning rather than teaching. The students are stimulated to have the motivation to learn something that must be learned and continues learning. However, students will not be forced to learn. While the integrated nature of the materials studied, the material associated with each other are united and in open-systems environment. In the educational characteristics of the individual gets a decent place.

Global creative, meaningful education has always stressed on a mental attitude to always bring something new and original. In paedagogis, creativity and democracy are two sides of the coin. Without democracy there would be no creative process, otherwise devoid of the creative process of democracy will have no meaning.Indonesia Education Society Against Globalization is a necessity, always showed two different faces, namely globalization, which show the face of the positive and negative impacts. The positive impact is acceptable to add to the list of assets in the world of education in Indonesia. As for the negative impacts, Refuse and avoid it is not possible, that can be done is to eliminate and reduce the negative impact. To deal with the negative impact of globalization on the world of education in Indonesia takes a firm stance on public education itself, namely:

Making reference Pancasila Pancasila as an ideology than as a nation of Indonesia, also acts as a filter, the influence of globalization, filtered and then classified into two groups:

1. The first group, which is in accordance with the character and personality of the Indonesian nation, this first class is a class that accepted and developed, in accordance with the character and personality of the nation.

2. The second category are the ones who do not fit the character and personality of the Indonesian nation. So that needs to be followed up to reduce the danger to the nation of Indonesia.

Making the lesson insightful moral as mandatory subjects, subjects that lead to the briefing moral, namely religious education, education Pancasila and citizenship, let used as a compulsory subject in the curriculum, so that students are required versed in scientific or specialization in certain disciplines, but also have a moral and character to personality.

\section{Effect of Globalization Education}

The influence of the forces of globalization according to the analysis rests on four strengths

1. Strength and Advances in science and technology, especially in the field of information and new innovations in technology that simplify people's livesFree trade supported by advances in science and technology 
2. Strength and regional and international cooperation that unites the life together of the nations of the world without any barriers limit state

3. Strength and increased awareness of human rights and human obligations in line with the spirit of mutual awareness.

The strength and progress of science and technology is accompanied by increasing the hardness of the globalization of the world, has had implications for the world of education, for example: all educational levels ranging from high school to higher education, both public and private and also opens international class program, This is to respond to market needs, a qualified workforce and increasingly stringent in the globalization of education.

Improving global insight is an important element to understand the problems of globalization, that is through education

1. The ability to anticipate / Anticipate, education means trying to prepare pupils / students to be able to anticipate the development of science and technology are so fast

2. Understand and cope with the situation / cope, meaning that it can develop the skills and attitudes learners to handle and deal with the new situation, as well as a sense of concern for the problem and the desire to solve the problem is a factor that must be developed in students.

3. Accommodate / a accommodate of science and technology means that it can accommodate the rapid perkembanagn with all the changes in the tackle, accommodate, need to be developed in students' attitudes are not miscible with the change, but he should be able to control the change in order to grow into a positive and beneficial to the lives of students

4. Mereoriantasi is the perception and insight into the world of globalization need to be reoriented, because science and technology development and rapid social change so as to obtain a broad insight.

Positive impact of globalization of Education

1. The more easily absorb the information access.

2. Globalization of education creates human international standard.

3. Globalization of education in Indonesia is able to compete with other negarara States.

4. Globalization will create a workforce that is qualified and able to compete

5. Changes in the education system to improve the quality of National Education

Negative impact of globalization of education

1. Indonesian education dominated and influenced by the owners of capital.

2. The world of education is highly dependent on technology, so that it becomes Instant.

3. Globalization affects some factions in the world of education.

4. Cultural acculturation impact occurs absorption of foreign culture.

\section{Responsibility Education in the era of globalization}

Problems of Globalization Education and influences that arise relating to education, such as teachers, students, parents, family, and an Environmental, that education globalization bias brings positive impact did change for the better, but also has a negative impact into a boomerang for the national education, everything will depend on the elements of education to be able to be responsive in the face of globalization

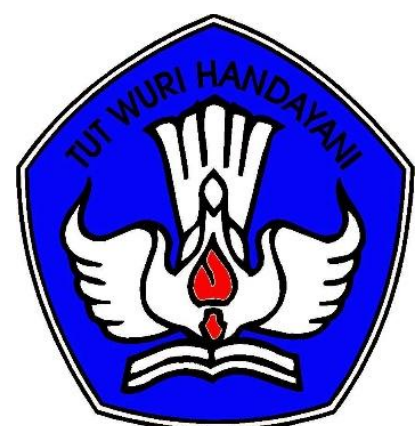

Figure 2. National Education Symbol

Teachers as professional educators with the primary task of educating, teaching, guiding, directing, train, assess, and evaluate students dijalur formal education, primary education and secondary education, teachers' current prosecuted as professionals, are able to increase the dignity, carrying out the education system national and realize national pendidikn, Printing learners become a man of faith and piety. Students should be able to pick and choose all the influences that go in him, be it the influence of friends, environment, and the mass media, the influence of globalization on students will very likely have a negative impact as for the positive or negative influence of globalization will be very apparent to students in his daily behavior. Students still in periods of instability, and growing who always wanted to try something that's new. 
Parents are regarded as the first educator for children before entering with the outside world, the influence of the family is also very big in the growth of a child, because in addition to having closeness emotionally, they also have this level of togetherness that is more because of living in one house, the role of parents to seek to know all activities performed by children outside of school. families must not fail because it will have an impact on the personality and behavior of children so uncontrolled, family responsibilities sometimes leave entirely to schools, teachers in educating and developing the potential of children, because control of the schools and teachers are limited to school hours. Neighborhood will have a major impact on the behavior and personality of a student, because of the influence of friends can beat the influence of teachers, parents and families. Dampat lifestyle environment also affects the order and norms that have been taught in school, about morals, behavior, respect teachers, and respect among friends.

\section{Symptoms of Globalization}

according to the National Council for the Social Studies (NCSS, 1982) suggests some of the symptoms or fenemona globalization process as follows:

1. Their evolution in the global transportation and communication systems.

2. Merging local economy, regional and national into the global economy.

3. Increasing the intensity of the interaction between people that creates a global culture as a guide of local cultural, regional and national variety.

4. The emergence of an international system that erodes boundaries internasioanal political traditions and national politics.

5. Improving the impact of human activities on ecosystems on earth

6. Increased global awareness that fosters awareness of the place of humanity in the earth as a member

7. Human beings, as the inhabitants of the earth and as a member of the global system.

\section{Universal Values in Education Globalization}

1. Universal values come from a variety of cultural traditions, national, multi-national and religious values. But no matter how there are different traditions, all nations have to support the same values regardless of time or geography, but tergantuk policy implementation in each of each country will vary according to the conditions for their countries.

2. The difference value of the Nation in culture is a manifestation of the diversity of values as a sovereign nation and perspective on the State of reflected on the feelings, choices, attitudes, lifestyles and views of the Country, which is the result of adaptation to the evolution of society and its environment is quite unique in order to meet the needs of Globalization ,

\section{Globalization Education System}

1. System Economic Education is a very complex system that raises the interdependence between countries, much further than just a causal link between consumers and producers in different regions, with economic power will always set the economic actors to import or upgrade export goods, cheaper products and competitive price and better quality.

2. Political education system is dominated by sovereign states and strong, this is a way to exert influence / influence and power / power, perhaps even more than the political system in the country is affected by global economic interests with regard to the distribution of natural resources. and organizational mechanisms play an important role in world politics which is parallel to the domestic politics of a country.

3. Education System Ecology of all species memdukung life, man is the perpetrator of the most critical in the system ecology because of its ability to manage and exploit, maintain be useful, a global education will invite the students to realize that there is a symbiotic relationship and interdependence of living creatures and the inanimate objects and overall human active role in ecology.

4. Education System Modern technology is not just changing patterns of life of individuals, in working and relating with other individuals and with the surrounding environment. Very very significant influence geopolitical change, the world economy functions, and global ecological systems. Many nations nation interdependence that characterizes globalization, due to technological advances very quickly in the field of transport and communications.

\section{History of Globalization Education}

History perspective that includes human values are diverse and universal, global and contemporary systems development, conditions and factors causing the emergence issues and global problems today as the foundation for global education. world history is a history that separates the territories of regional and inter-state relations, generally, all the historical focus on the development of countries stronger. 
The traditional approach to study the history of the world is still sediki, understanding the interdependence among nations with this approach does not emphasize the historical roots of the of the nation of useful functions of the skeleton is built, is to measure the feasibility of the program as a guideline for developing the educational curriculum globa, so all an essential part of all disciplines such as history, sociology, geography, politics, economics and culture and others.

\section{Bibbliography}

[1]. Sanusi, Ahmad (2016). Pendidikan untu Kearifan, Mempertimbangkan Kembali Sistem Nilai, Belajar dan Kecerdasa, Editor Iriantara Yosal, Bandung, Nuasansa Cendikia.

[2]. Mulyasa, E; (2016). Guru dalam Implementasi Kurikulum 2013, Jadilah Guru Profesional atau tidak sama sekali. Bandung, Remaja Rosda karya.

[3]. Sauri Sofyan, Firmansyah Herlan (2010). Meretas Pendidikan Nilai, Bandung Arfino Raya

[4]. Aisyah, Siti. (2008). Pembelajaran Terpadu Buku materi Pokok PGTKJakarta: Universitas Terbuka.

[5]. Azwar, S. (2010). Sikap manusia, teori, dan pengukurannya. Yogyakarta: Pustaka Pelajar

[6]. Chang, M. (2009). An appraisal perspective of teacher burnout: examining the emotional work of teachersEducational Psychology Review.

[7]. Detik.(2010). Tuntut Kesejahteraan, Ratusan Guru TK Geruduk Kantor Dewan.

[8]. Knox, Jeffrey Anton (2011). Teachers' Perceptions of Job Satisfaction and School Climate in an Era of countability:A Mixed Methods Study of Two High Schools on Tennessee's High Priority List.

[9]. Indriyanto Agus, Kuswanjono Arqom (2012). Agama Budaya dnan Bencana, Kajian Integratif Ilmu Agama dan Budya, Bandung, Pustaka Mizan

[10]. Oktarina, Nina (2007). Peranan Pendidikan Global dalam Meningkatkan Kualitas Sumber Daya Manusia 